\title{
Utilization of Library Information Resources by Undergraduate Students of University Of Medical Science Ondo, Ondo State, Nigeria
}

\author{
Fasa Rachael Aladeniyi (Cln) \\ Polytechnic Library \\ Rufus Giwa Polytechnic Owo, Ondo State \\ Nigeria \\ Temitope Samuel Owokole \\ Department Of Library and Information Science \\ Rufus Giwa Polytechnic Owo \\ Ondo State \\ Nigeria
}

\begin{abstract}
Library information resources are vital tools in academic libraries. The success of any library depends on its resources and the utilization of the resources. This study examined the utilization of library information resources by undergraduates students of University of Medical Science, Ondo, Ondo State, Nigeria. Descriptive research design was employed for the study. The population of the study was the registered users of the library for 2016/2017 academic session. Availability sampling technique was used for the study. In this case only the students library user that were available in the library as at the time of this research were used for the study. Questionnaire was used as the instrument for data collection. A total of two hundred and seventy six (276) copies of questionnaire were administered and two hundred and thirty four (234) copies were retrieved from the respondents. The data gathered through the questionnaire were analyzed through the use of frequency count and simple percentage. According to the findings the respondents agreed to the availability of all the listed resources in the questionnaire. Majority of the respondents use the library information resources for the purpose of obtaining general information, for examination, for assignment and for research. The findings also revealed that majority of the respondents use the library information resources occasionally, while textbooks were found to be the most utilized library resources by the respondents. As revealed in the findings, only few respondents indicated that they were having challenges in their utilization of library information resources. Based on the findings of the study, some recommendations were made to enhance better use of the library information resources in the University of Medical Science Ondo, Ondo State, Nigeria.
\end{abstract}

Keywords: Library information resources, Undergraduate, Students, University, Medical Science.

\section{Introduction}

Library information resources are essential tools in teaching and learning process of any academic community. Members of the academia need library information resources for teaching, learning research, update of knowledge and personal development. Library information resources are materials or information resources acquired by the library to meet the information needs of library patrons. Barfi, Afful-Authur and Agyapong (2013) define library information resources as the raw materials that provide vital services in the teaching and learning process. The survival and success of any tertiary institution depends on the library. The library is regarded as a pillar that holds institution of higher learning. Agbaje defined library as an organized collection of sources of information and similar resources made accessible to a specific community for references or borrowing. Agbaje explained that the resources may be physical, digital in a physical building or visual space. The relevance of a library in higher institutions of learning such as University, Polytechnics and Colleges of Education cannot be over-emphasized. Onye (2016) acknowledge that the value of library cannot be overemphasized considering that any students no matter how brilliant cannot ignore the library. Onye also note that without the information resources provided by the library, teaching, learning, research and other reasons for using the library resources will lack requisite support. 
Okiki (2013) posit that the library is a vital facility for enhancing learning, teaching and research. Okiki affirmed that it is the hub of all academic activities established to prove intellectual excellence. A library can only be regarded as the hub of all academic activities where there are adequate library resources that are well utilized. The worth and impact of a library can be felt through the utilization of the various resources acquired by the library. Effective utilization of the library information resources will no doubt add value to the functions of the library in any society.

\section{Brief History of theUniversity of Medical Science Ondo (UNIMED)}

University of Medical Science, Ondo was established 2015 in Ondo, Ondo State Nigeria under the administration of Governor Olusegun Abayomi Rahman Mimiko as the Executive Governor of Ondo State. Ondo state was created from the Old Western Region of Nigeria on February 6, 1976. University of Medical Science Ondo is the Third Specialized Medical University in Africa and Nigeria First Specialized Medical University to be accredited by the National University Commission. Presently, the University has six faculties where courses on medical sciences and other related areas are taught to produce graduates of high standard capable of providing quality services in their various areas of specialization.

\section{Statement of the Problem}

The library is regarded as an information centre charged with the responsibility of selecting, acquiring and organizing various information resources to meet the needs of its users. Library renders essential services in tertiary institutions of learning. It supports the academic programmes of the parent body by providing relevant information resources that is capable of ensuring success when utilized. Meaningful academic success can only be achieved when there is a functional library with adequate information resources that are well utilized. Anyanwu (2015) posit that the value of a library collection lies in its effective utilization by the user community. Onifade, Ogbuiyi and Omeluzor (2013) cited in Olajide and Adio (2017) acknowledged that the major aim of any University library is to support teaching, learning and research activities of its parent institution. They emphasized that University must therefore, make sure that their resources are well utilized as this is essential for educational development of students.

In any tertiary institution, students have the largest population than any other members of the academic community and they are also expected to be one of the major users of an academic library. Since students users are expected to be one of the major users of an academic library. There is a need for studies to be conducted regularly on the utilization of the library information resources. This will also serve as a channel to access the impact of the library on the user community. In view of the foregoing, this study therefore attempts to investigate the utilization of library information resources by undergraduate students of the University of Medical Science, Ondo, Ondo state, Nigeria.

\section{Objective of the Study}

The main objective of this study is to investigate the utilization of library information resources by undergraduate students of University of Medical Science, Ondo.

The study has the following specific objectives;

i. To find out the available library information resources in University of Medical Science, Ondo, Ondo State.

ii. To identify the purpose for which the students utilized the library information resources in their institution library

iii. To determine how frequent the students use the library information resources.

iv. To find out the most utilized library information resources.

v. To investigate the challenges hindering the effective utilization of the library information resources in the University of Medical Science Ondo.

\section{Research Questions}

This study is guided by the following research questions;

i. What are the available library information resources in the University of Medical Science Ondo, Ondo State?

ii. For what purpose do the students of the University of Medical Science Ondo use the library information resources in their institution library.

iii. How frequent do the students utilized the library information resources in their institution library? 
iv. Which of the library information resources do the students utilized most?

v. What are the challenges hindering the effective utilization of the library information resources in the University of medical science Ondo?

\section{Literature Review}

Library plays a significant role in academic community. The place of libraries and its information resources in tertiary institutions cannot be relegated. Aladeniyi \& Arikawe (2017) acknowledged that libraries are very essential in any organization, especially in higher institutions of learning. Library information resources are vital ingredients in the library. They enable libraries to render their services to the user community. A library without resources will lose its relevance in the society. Jegede (2010) defined library resources as those materials made up of books, audio-visual materials, software media, audio-visual hardware and other materials used in teaching and learning process in the library. Adomi (2006) opine that library resources are the information bearing materials that enable the library to fulfill its goals of meeting the information needs of its users.

According to Ojedokun (2007) Basically library resources are materials that user consult in making decision and also for problem solving these sources could be primary or secondary. The relevance of a library depends on the utilization of its resources. Agboola \& Bamigboye (2011) agreed that the need for good libraries in higher institutions of learning cannot be over-emphasized, as the quality of any education depends on the library, not the library as a magnificent building but the use of it. They note that, it is important that libraries serving academic communities have the broadest possible collections of books and other essential materials.

Mamo \& Amidu carried out a study on the determinant of library resources use by lecturers of College of Agriculture, Lafia, Nasarawa State, Nigeria. They maintained that the advancement of an academic staff unlike other staff depends largely, if not entirely on his research output which depends critically on the availability of suitable facilities, including adequate library resources. Barfi, Afful-Authur and Agyapong (2017) affirmed that availability of library resources create an enabling environment for the utilization of library resources and this will provide teaching and learning. Uzoagba, Ezukwuoke and Chiagbu (2012) affirmed that library resources in print, non-print and electronic forms are the major components of any library. Onye (2016) observed that the objectives of library may not be realizable unless its resources reach optical capacity and use by faculty and students who depend on its information resources for different purposes.

Regarding the type of information resources available Onye reported that all the participants in their study (100\%) indicated that textbooks are available in the library while $572(84 \%)$ confirmed that the library has computers, 314 $(46.1 \%)$ show the presence of internet and 90 (13.2\%) indicated that the library possessed films (audio-visual). Olajide \& Adio (2017) examined the effective utilization of University library resources by under-graduate students at the Federal University Oye-Ekiti, Nigeria. They found that library resources like abstract, indexes, yearbooks, atlas were neither satisfactory nor readily available for use. In tertiary institutions, library information resources are use for different purpose. Agyekummer and Filson (2012) found in their study that most of the students use library resources and services to supplement their class notes, assignment and helped them in examination preparation.

Clabo, (2002) pointed out that students use library resources for recreational readings, for reference purposes, doing their assignment and reading news from newspapers Foloruso \& Njoku (2016) study shows that most prominent purpose of using the library resources was to study and read for examinations. Many of the students also use the library to search for materials for assignments and to do research work, as well to read newspaper or participate in a group discussion. Amusa \& Iyoro (2013) observed in their study that majority of the students (60\%) used the library resources to study, read and also for research.

Agboola \& Bamigboye (2011) in their study they reported the extent of use of library resources either in print or electronic form in each of the three University they examined. Their findings shows that at U.I 181 (49\%) respondents said they made use of it very often, 120 (32\%) said often, $40(11 \%)$ said occasionally while only 31 $(8 \%)$ said they made use of resources in the library. At UNAAB, $110(40 \%)$ indicated very often, $95(34 \%)$ said often, $53(19 \%)$ said occasionally while $20(7 \%)$ indicated never. In OOU, 60 (23\%) indicated very often, 56 (21\%) said often, 88 (34\%) said occasionally while 58 (22\%) said never. Oluwatobi, Ehiogbae, Aluko-Arowolo and Onasote (2014) study revealed that most frequently used library materials is online database and this is followed by Dictionaries, books, encyclopedia which are used daily while the least use materials is CD-ROM database. Okiy (2000) study indicated that respondents used books more than other materials. 
On the challenges hindering the effective utilization of library in formation resources Uzogbu, Ezukwuoke and Chingbu (2012) reported in their study that factors such as unavailability of resources ranked highest with $42 \%$, power failure followed with $27 \%$ while disorganized materials ranked third with $17 \%$, while those who claimed that there was no problem were $11 \%$ of the respondents. Mamo \& Amidu (2016) found that lack of current information resources and improper shelving of information resources are the major factors hindering the effective use of library resources. Olajide \& Otunla (2015) findings show that the major challenge faced by respondents is lack of time. The study of Barfi, Afful-Arthur and Agyupong (2018) indicated that noninvolvement of lecturers in book selection, few up-to-date materials, users not informed of new arrivals, poor library instruction, unavailability of automatic generator to power sockets and inadequate library staff are factors that actually hinder or impede the use of library materials by lecturers.

\section{Methodology}

Descriptive survey method was adopted for this study. The study population is the undergraduate registered library users of University of Medical Science Ondo, Ondo State Nigeria for 2016/2017 academic session. The total population of the registered users according to the data obtained as at the time of this research was five hundred and sixty (560). This comprises students from all the faculties of the Institution. Availability sampling technique was used in selecting the sample size for this study. In this case undergraduate users that were present in the library were used as the sample size. The sample size was 276. Questionnaire was used as the only instrument for data collection. The questionnaire was in two parts. Section A was on demographic characteristics of respondent and Section B was based on the research questions. A total of two hundred and seventy six (276) questionnaire were administered and two hundred and thirty four (234) were retrieved from the respondents. This was carried out for a period of two days. The data gathered from the respondents were analyzed through the use of frequency count and simple percentage.

\section{Data Analysis and Interpretation}

Table 1 revealed the number of respondents according to gender. The analysis shows that the female respondents were more than the male respondents, having 155 (66.2\%) while the male respondents has $79(33.8 \%)$. This finding therefore shows that the female undergraduate library users are more than their male counterparts.

\section{Table 1: Gender of Respondents}

\begin{tabular}{|l|l|l|}
\hline Gender & No. of Respondents & Percentage \% \\
\hline Male & 79 & 33.8 \\
\hline Female & 155 & 66.2 \\
\hline Total & $\mathbf{2 3 4}$ & $\mathbf{1 0 0 \%}$ \\
\hline
\end{tabular}

As indicated in table 2, 100 level recorded a total of $161(68.8 \%)$ response rate, 200 level $73(31.2 \%)$. However, there was no respondents from 300 level. This is because they were not available on campus when the questionnaires were administered. It is worthy to note that the pioneer students of the institution at the time of this research were in 300 level, being a new school established in 2015.

Table 2: Level of Respondents

\begin{tabular}{|l|l|l|}
\hline Level & No. of Respondents & Percentage \% \\
\hline 100 & 161 & 68.8 \\
\hline 200 & 73 & 31.2 \\
\hline 300 & - & - \\
\hline Total & $\mathbf{2 3 4}$ & $\mathbf{1 0 0 \%}$ \\
\hline
\end{tabular}

Table 3 revealed the response rate of respondent on the available library resources in University of Medical Science Library Ondo. As indicated in the table majority of the respondents agreed to the availability of all the listed resources in the library. The table also shows that all the respondents agreed that textbooks are available in their library having 234 (100\%) response rate. 
Table 3: Available Library Resources

Research Question 1: What are the available Library Resources in your Library?

\begin{tabular}{|l|l|l|l|l|}
\hline Available Library Resources & Agree & \% & Disagree & \% \\
\hline Textbook & 234 & 100 & - & - \\
\hline Journal & 216 & 92.3 & 18 & 7.7 \\
\hline Directories & 201 & 85.9 & 33 & 14.1 \\
\hline Handbook & 213 & 91.0 & 21 & 9.0 \\
\hline Manuals & 199 & 85.0 & 35 & 15.0 \\
\hline Newspaper \& Magazines & 214 & 91.5 & 20 & 8.5 \\
\hline Report & 181 & 77.4 & 53 & 22.5 \\
\hline Atlases/Maps & 186 & 79.5 & 48 & 20.5 \\
\hline Dictionary & 228 & 97.4 & 6 & 2.6 \\
\hline Internet & 226 & 96.6 & 8 & 3.4 \\
\hline Computer & 217 & 92.7 & 17 & 7.3 \\
\hline Biographies & 189 & 80.8 & 45 & 19.2 \\
\hline Abstract/Indexes & 163 & 69.7 & 71 & 30.3 \\
\hline Encyclopedia & 210 & 89.7 & 24 & 10.3 \\
\hline Audio-visual material & 188 & 80.3 & 46 & 19.7 \\
\hline
\end{tabular}

Table 4 revealed the various purpose of utilizing library information resources by the students of the University of Medical Science, Ondo. From the analysis, majority of the respondents agreed that they use the library resources for the purpose of obtaining general information, for examination, for assignment and for research having 231 (98.7\%), 224 (95.7\%), 220 (95\%) and 217 (92.7\%) respectively.

\section{Table 4: Purpose of Utilizing the Library Information Resources}

Research Question 2: What are your Purpose of Utilizing the Library information Resources in your institution library?

\begin{tabular}{|l|l|l|l|l|}
\hline Purpose of Utilizing & Agree & \% & Disagree & \% \\
\hline For research & 217 & 92.7 & 17 & 7.2 \\
\hline For obtaining general information & 231 & 98.7 & 3 & 1.2 \\
\hline For current affairs & 174 & 74.3 & 60 & 25.6 \\
\hline For examination purpose & 224 & 95.7 & 10 & 4.2 \\
\hline For assignment purpose & 220 & 94 & 14 & 6 \\
\hline For sport information & 110 & 47 & 124 & 53 \\
\hline For personal development & 137 & 58.5 & 23 & 98. \\
\hline
\end{tabular}

The findings also shows that respondents who use the library information resources for the purpose of obtaining information on sport has the lowest response rate with 110 (47\%). Table 5 shows that majority of the respondents $119(50.9 \%)$ agreed that they use the library information resources occasionally. This is followed by respondents that indicated that they use the library information resources often $73(31.2 \%)$.

Table 5: Frequency of use of Library Information Resources

Research Question 3: How often do the students use the library information resources?

\begin{tabular}{|l|l|l|}
\hline Frequency & No. of Respondents & Percentage \% \\
\hline Very often & 42 & 17.9 \\
\hline Often & 73 & 31.2 \\
\hline Occasionally & 119 & 50.9 \\
\hline Never & 0 & 0 \\
\hline Total & $\mathbf{2 3 4}$ & $\mathbf{1 0 0 \%}$ \\
\hline
\end{tabular}

Respondents that use the library information resources very often recorded 47 (17.9\%). The analysis also shows that non of the respondents indicated that they never use the library resources. The findings in table 6 shows that textbooks are the most consulted library information resources, having $118(50.4 \%)$. 
This is followed by internet (12.8\%).this findings corroborate Okiy (2000) which indicated that respondents use books more than other materials.

Table 6: Most Utilized Library information Resources

Research Question 4: Which of the Library Information Resources do you Utilized most?

\begin{tabular}{|l|l|l|}
\hline $\begin{array}{l}\text { Most Utilized Library Information } \\
\text { Resources }\end{array}$ & No. of Respondents & Percentage \% \\
\hline Textbook & 118 & 50.4 \\
\hline Journals & 12 & 5.1 \\
\hline Directories & 3 & 1.3 \\
\hline Handbook & 13 & 5.6 \\
\hline Manuals & 6 & 2.6 \\
\hline Newspapers \& Magazines & 14 & 6.0 \\
\hline Reports & - & - \\
\hline Atlas and Maps & 5 & 2.1 \\
\hline Directories & 15 & 6.4 \\
\hline Audio-visual materials & 3 & 1.3 \\
\hline Internet & 30 & 12.8 \\
\hline Computer & 5 & 2.1 \\
\hline Biographies & - & - \\
\hline Abstract \& Indexes & - & - \\
\hline Encyclopedia & 10 & 4.3 \\
\hline
\end{tabular}

Table 7 indicated the challenges that respondents faced in their utilizations of library information resources. It can be seen from the table that only few respondents agreed that they were having challenges, while majority of the respondents indicated that they were not having challenges.

Table 7: Challenges Hindering the Effective Utilization of Library Information Resources in university of medical science, Ondo

Research Question 5: What are the challenges hindering the effective utilization of library information resources

\begin{tabular}{|l|l|l|l|l|}
\hline $\begin{array}{l}\text { Challenges Hindering the effective Utilization of } \\
\text { Library Information Resources }\end{array}$ & Agree & $\%$ & Disagree & \% \\
\hline Lack of adequate resources on my field of study & 41 & 17.5 & 193 & 82.5 \\
\hline Noise from fellow students & 48 & 20.5 & 186 & 77.5 \\
\hline Inadequate sitting facilities & 34 & 14.5 & 200 & 85.5 \\
\hline Lack of information retrieval skills & 44 & 18.8 & 190 & 81.2 \\
\hline $\begin{array}{l}\text { Inadequate personnel in the library to assist in getting } \\
\text { needed information }\end{array}$ & 47 & 20.1 & 187 & 79.9 \\
\hline Lack of internet facilities & 24 & 10.3 & 210 & 89.7 \\
\hline Lack of up-to-date resources & 20 & 8.5 & 214 & 91.5 \\
\hline Inadequate power supply in the library & 18 & 7.7 & 216 & 92.3 \\
\hline Poor arrangement of the library materials & 23 & 98 & 211 & 90.2 \\
\hline
\end{tabular}

\section{Conclusion}

Library information resources are vital ingredients in academic libraries. Its function's cannot be over emphasized when it is full utilized this study has provided data on the utilization of library information resources by undergraduate students of the University of Medical Science, Ondo, Ondo state Nigeria. The major findings of the study are

i. The female respondents are more than the male respondents

ii. 100 level has the highest number of respondents

iii. Majority of the respondents agreed that Books, Journals, Directories, Handbook, Manuals, Newspapers and Magazines, Reports, Atlases/Maps, Dictionary, Internet, Computer, Abstracts/Indexes, Encyclopedia and Audio-Visual materials are available in their Institution libraries. 
iv. Majority of the respondents agreed that they use the library information resources for the purpose of obtaining general information, for examination, for assignment and for research while those that indicated that they use it to obtain information on sport recorded the lowest response rate.

v. Textbooks are the most utilized library information resources by the respondents.

vi. Only few respondents agreed that they are having challenges in the utilization of library information resources.

\section{Recommendations}

Following the findings of this study the following recommendations were made to enhance better use of the library information resources in the University of Medical Science Ondo, Ondo state.

i. Male students should be encouraged to use the library like their female counterparts

ii. The students should also be encouraged to use other resources that are underutilized.

iii. Some of the challenges hindering the use of library information resources such as noise from fellow students, Inadequate personnel in the library to assist in getting needed information as indicated by few of the respondents should be addressed by the management of the library and the management of the institutions.

\section{References}

Adomi, E. E. (2006). Collection Development and Management. Benin City: Ethiope.

Agbaje, A.A. (2014). The role of Library and Effective Education. Paper presented at 2014 Annual General Meeting/Conference Vand Award Ceremony of the Ondo State Chapter of Nigeria Library Association on 3rd December 2014 at Francis Idibuge Auditorium, Federal University of Technology (FUTA), Akure, Ondo State, Nigeria.

Agboola, O.I \& Bamigboye, B.O (2012). Students level of study user of library resources in Nigeria Univeristy: A Comparative Study, Library Philosophy and Practice. Available at http://unllib.uni.edu//pp/

Agyekumaner, B.A \& Filson, C.K (2012). The Challenges of School Libraries after the Implementation of the New Educational Reforms in Ghana. Library Philosophy and Practice (e-journal) available at: http://digidtalcommons.unl.edu/libphilprac/932.

Aladeniyi, F. R. \& Arikawe, S. A. (2017). A Survey on the Use of Library Information Resources by Students of Ondo State School of Nursing Akure, Ondo State Nigeria. International Journal of Innovative Research and Development. 6 (9).

Amusa, O.I \& Iyoro,A.O (2013). Influence of Library Environments Instructional Programmes, and UserLibrarian Collaboration on Library Use by Undergraduate Student in Nigeria: Chinese Librarianship: An International Electronic Journal 35:72-86. URL:WWW.ICLC.US/Cliej/C/35AI.

Anyanwu, N. E. (2015). Evaluating Undergraduate Students Awareness and Use of Medical Library Resources: A Study of Nnamdi Azikiwe University Nigeria, International Journal of Library Science. 4(3):56.

Barfi, K. A., Afful-Arthur, P. \& Agyapong, E. M. (2018). Utilization of Library resources by lecturers in University of Cape Coast. International Journal of Library and Information Science 10(1), 10-16.

Clabo, C. A. (2002). Study Of The Library Use Practices Of High School Students In There EastElectronic These And Dissertations. Paper 635 Accessed From: Http://Dc.Etsu.Edu/Etd/635.

Folorunso, O. \& Njoku, E. (2016). Influence Of Library Environment And User EducationOnUndergraduates. Use Of Library At The University Of Ibadan Nigeria. European Scientific Journal. 12 (19).

Jegede, O. (2010). Problems of Acquisitions of Library Materials in a Developing Country. University of Lagos Experience. International Library Review, 9(2), 225-239.

Mamo, U. I. \& Amidu, G. (2016). The determinant of library resources use by lecturers of College of Agriculture, Lafia-Nasarawa State, Nigeria. IOSR Journal of Humanities and Sciences (IORS-Jihss) vol. 21, 11, (Nov.59-62.

Ojedokun. A.A (2007). Information Literacy of Tertiary Education Students in Africa. Ibadan: Third Wrld Information Services Limited.

Okiki, C.O (2013). Availability of information resources for research output: perception of Academic staff members in Nigerian Federal Universities. International journal of computer science and telecommunications. 4(8), 2013. 
Okly, R. B. (2000). Assessing Students and Faculty Use of Academic Libraries in Nigeria. The Study of Delta State University Abaaraka. Frontiers of Information and Information Science 2(2):96-101.

Olajide, O. \& Adio, G. (2017). Effective Utilization of University Library Resources by Undergraduate Students: A Case Study of Federal University Oye-Ekiti, Nigeria: Library Philosophy and Practice (e-journal). 1503. http://digitalcommons.uni.edu/lib-philprac/1503.

Olajide, A.A. \& Otunla, O.A. (2015). Use of Information Resources by Students Nurses. Library Philosophy and Practice (e-journal). Available at http://digitalcommons.unl.edu.Libphilprac/1255.

Oluwatobi, I. Ehioghae, Aluko-Arowolo \& Onasole (2014). Utilization of Library Resources for Effective Research Output among Post-graduate Students in Adventist University of Africa. Global Advanced ResearchJournal of Social Sciences (GARJSS) 3(4),052-057. Available Online: http://garj.org/garjsa/index.htm

Onye, U. U. (2016). Availability, Accessibility and Utilization of Library Information Resources by Student of the Federal University of Technology, Owerri (FUTO), Information \& Knowledge Management. 6, (10).

Uzoagba, Ngozi, C., Ezukwuoke, Nelson, I., \& Chiagbu, Emma (2012). Effective service Delivery in Medical Library College of Medicine, University of Nigeria, Enugu Campus. Owena Journal of Library and Information Science. 4 (1\&2). 